\title{
Political Repression and Government Effectiveness
}

\author{
William R. DiPietro ${ }^{1}$ \\ ${ }^{1}$ Business Department, Daemen College, Amherst, New York, United States \\ Correspondence: William R. DiPietro, Business Department, Daemen College, Amherst, New York, United \\ States. E-mail:wdipietr@daemen.edu
}

Received: January 22, 2016

Accepted: February 4, 2016 Online Published: February 26, 2016

doi:10.20849/ajsss.v1i1.14

URL: http://dx.doi.org/10.20849/ajsss.v1i1.14

\begin{abstract}
It seems logical that when a state is doing a good job with regard to the economy, infrastructure, education, and the provision of public goods, citizens will be less disenchanted with their government and less prone to either condone or engage in any form of dissident behavior requiring enhanced state repression. Given this reasoning, this paper formally proposes that state repression is negatively related to government performance, and uses cross country regression analysis to test the notion. The results of the empirical investigation provide support for the idea. Thus, it appears, just as theoretically proposed, that governments that work well, have less need to use force against their citizens, and repress less.
\end{abstract}

Keywords: state repression, government performance, regression analysis

\section{Introduction}

State repression is an ugly matter. Human beings want to live without fear, especially fear from their own government. Reducing state repression, or bringing state repression under control, requires greater understanding of state repression and of the underlying reasons for state repression.

While a host of other variables have been found to influence repression, this paper hypothesizes that government effectiveness may be an important determinant of state repression. It theorizes that higher levels of government effectiveness lead to lower levels of repression, and that lower levels of government effectiveness lead to greater repression. A government that does not sustain a healthy economy and fails to adequately provide for public goods is likely to spawn dissatisfaction in its population, and create a fertile environment for dissent, and the emergence of both more, and more powerful, dissident groups. The higher is the level of dissent, and greater is the number and strength of dissident groups, the more the government is likely to find it necessary to resort to repression in order to keep the situation under control and forestall any threat to its continual existence.

The organization of the paper is as follows. The first section provides a small sample of the recent literature that looks at the causes of state repression. The second section develops a formal model centering on government performance as a determinant of state repression. The third section talks about the variables that are used in the empirical analysis, and identifies the data sources for each of these variables. The fourth section presents the results from cross country regressions of state repression on government effectiveness and other variables. The fifth section concludes.

\section{Background Literature}

Nordas and Davenport empirically look at whether youth bulge (large percentages of the population in the fifteen to twenty four year old cohort) is associated with greater government repression (Nordas \& Davenport, 2013). Using a panel of one hundred and eighty countries for the years 1976 through 2000, and controlling for the level of economic development, the size of the population, the amount of decent, the extent of intrastate armed conflict, and past levels of repression, their ordered probit regressions indicate, consistent with their hypothesis, that political repression is positively related to youth bulges.

Ritter develops a game theory model that predicts that when the probability of executive political survival increases, the onset of repression and of dissent decreases, but the severity of repression and of dissent increases (Ritter, 2014). Using a two stage tobit model on country data for the years 1990 through 2004, she regresses the likelihood of repression, the likelihood of dissent, the severity of repression, the severity of dissent on job 
security of the executive after adjusting for a number of other variables. The results, in general, are in conformity with the predictions of her theoretical model.

Civil war within a country is a major challenge to the existence of the prevailing government of a country, and is universally acknowledged as a major reason for state repression. However, it may also be that greater civil conflict in neighboring countries can lead to increased repression in a country, even in a country that is not presentably experiencing civil war. In this case, repression may be used as a preemptive measure to reduce the chances of civil war taking root. Danneman and Ritter, using a Bayesian mulitlevel model on data from 1981 to 2004 , find support for their central hypothesis that greater repression occurs in states that are in geographic neighborhoods where other states are subject to higher levels of civil conflict (Danneman \& Ritter, 2012).

Gibler looks at the potential link between repression and U.S. foreign aid. He argues that U.S. Foreign aid reduces repression because decision makers in potential aid recipient countries take into account the opportunity cost of lost U.S. foreign aid from repressive activity (Gibler, 2008). Developing a measure of the opportunity cost of U.S. aid, he undertakes econometric analysis on data for one hundred fifty two potential aid recipient countries over a twenty nine year period, and finds evidence that increased opportunity cost of U.S. aid increases respect for human rights in aid recipient countries.

Using a data set composed of one hundred sixty six countries for the years 1977 to 2001, Wright looks at changes in repression that may occur from interstate territorial conflict to acquire land (Wright, 2014) in his ordered probit regressions of state repression on a measure of the existence and intensity of interstate territorial conflict, he finds that high intensity interstate conflict of revisionist states seeking to increase their territory increases the likelihood of state repression in democracies, but not in autocratic states. In addition, his regressions also show that, for both democracies and autocracies, population size and civil conflict have a positive effect on state repression.

Wood empirically investigates the relationship between state repression and economic sanctions (Wood, 2008). He argues that sanctions, by placing financial constraints on targeted governments and thereby diminishing their ability to distribute resources to regime supporters and to provide needed public goods, because increased political instability. The uptick in political instability from sanctions, in turn, leads to higher levels of repression. Wood's ordered probit regressions looking at U.S. and U.N. sanctions on one hundred fifty seven for the period 1976 through 2001, indicate, consistent with his theory, that both sanctions and the severity of sanctions increase the likelihood of state repression. His regressions also suggest that greater democracy, greater economic growth, and higher levels of economic development are likely to reduce the amount of state repression, while, greater decent, bigger population size, and the presence civil war, or of the cold war are apt to increase repression.

In an age of globalization when foreign direct investment by multinationals is rapidly expanding, a natural question that arises is whether foreign investment might be consequential for state repression. Sorens and Ruger test whether state repression is related to structural dependency due to foreign investment (Sorens \& Ruger, 2012). Using two different measures of repression as their dependent variable in their regressions, a cross country time series data set that imputes numbers for missing values, and the percentage of foreign direct investment stock to gross capital formation to quantify structural dependence, they find little evidence that structural dependence from foreign direct investment matters for state repression. However, they do find that a host of other commonly employed variables to explain state repression are statistically relevant for repression. These include democracy, GDP per capita, trade, internal conflict, civil war, and population size.

Mitchell, Ring and Spellman consider whether differences in the legal systems between countries might influence repression (Mitchell, Ring, \& Spellman, 2013). In their empirics, they use cross country data from 1976 through 2006, and run ordered logit regressions of repression on a set of legal tradition dummies, judicial independence, colonial legacy, and a group of control variables commonly used in the literature to explain repression. Their findings show that common law reduces repression relative to Islamic and civil law, that greater judicial independence lowers repression, and that colonial legacy is associated with reduced repression. With regard to their control variables, their results that democracy, GDP per capita, population size, reduce repression, while lagged repression and civil war increase repression.

\section{The Model}

The model is a single equation that simply theorizes that state repression is a function of government performance. Formally, the model is as follows.

$$
\mathrm{R}=\mathrm{f}(\mathrm{P}, \mathbf{C}) \delta \mathrm{R} / \delta \mathrm{P}<0
$$


In the equation, $\mathrm{R}$ stands for the amount of state repression, $\mathrm{P}$ is state performance, and, $\mathbf{C}$ represents a set of control variables.

Better state performance, more effective government, is expected to lead to less state repression. Fundamentally, this is because more effective government reduces the government's need to use repression in order to maintain its hold on power. A government's legitimacy in citizens' eyes is based on its performance. It was because of its failure to deliver, its failure to provide substantive economic growth and to improve the standard of living that ultimately lead to the disintegration of the powerful Soviet Union. A government that effectively and efficiently provides high quality government services and nicely runs the economy is going to have more contented citizens, citizens who favor their government and oppose subversive activity, and a country that is less less likely to span dissident groups.

In addition to government performance, three control variables are considered as potential determinants of state repression. They are the impact of terrorism in a country, the extent of organized crime, and the size of the population.

It is anticipated that there will be a positive relationship both between government repression and the degree a country is subject to terrorism, and between government repression and organized crime.

Within its border, a government can legally use force to impose its will on those within its territory, and, quite naturally, it jealously guards this ability. Any group that assumes power on its own invading the government's treasured turf and exclusive prerogative, or anything that poses a challenge or threat to the government's existence, the government will try to eliminate or reduce, through repression or other means. Two prominent problems facing the government of this sort are terrorism and organized crime. Both terrorism and organized crime employ force or the threat of force to achieve their objectives. Terrorists harm innocent people and destroy property, thereby, undermining the ability of the government to maintain law and order, and facilitating the questioning by ordinary citizens of the government's ability to keep them safe. Successful organized crime can create a quasi-government organization on its own, with enormous revenues not subject to taxation pouring in from racketeering, extortion, drugs, prostitution, and other criminal activity, along with a completely independent enforcement arm composed of heavies and hit men.

The final control variable, the size of the population, is a variable that is commonly used to explain differences in state repression between countries. Just as the case with terrorism and crime, population size is expected to be positively related to state repression. The basic reasoning is that controlling the population is more difficult the larger is the population of the country.

\section{Sources for the Variables}

The measure of political repression is the political terror scale for 2010 (Political Terror Scale, 2010). The political terror scale ranks countries from one to five with higher values indicating greater repression of the population by the government. The political terror scale represents an average of separate evaluations made by the U.S. State Department and by Amnesty International.

Government performance is quantified by using the government effectiveness index of the World Bank for 2010 (World Bank, 2014). The government effectiveness index takes into account the perceptions of the quality of public services, the quality of the civil service, and the quality of public policy. The range of the government effectiveness index is from negative 2.5 to positive 2.5 with higher values indicating greater government effectiveness.

Terrorism is captured by employing terrorism index for 2013 of the Institute for Economics and Peace (Institute for Economics and Peace, 2015). The index tries to capture the impact of terrorism in a country by considering terrorist incidents, deaths and casualties, and property damage resulting from terrorism. The index has a potential range between zero and ten.

The impact of organized crime is calculated from the World Economic Forum's organized crime index for 2009-2010 (World Economic Forum, 2011). The World Economic Forum's organized crime index is a weighted average of answers to the survey question, "Does organized crime (mafia-orientated racketeering, extortion) impose costs on businesses in your country?", with potential answers ranging from one, significant costs, to seven, no costs at all. Because higher values of the Forum's organized crime index indicate, not higher, but lower costs of organized crime to business, the organized crime measure used in the paper is eight minus the Forum's organized crime index. Thus, in an intuitively appealing manner, higher values of the crime measure in the paper spell higher costs of business resulting from greater levels of organized crime in a country. 
Finally, population comes from the World Bank, and is measured by total numbers of individuals in a country for the year 2010 (World Bank, 2014).

\section{Empirical Findings}

Table 1 shows the results of cross country regressions of state repression on government effectiveness and other variables.

Table 1. Cross country regressions of state repression on government effectiveness and other variables

\begin{tabular}{lllll}
\hline & $(1)$ & $(2)$ & $(3)$ & $(4)$ \\
\hline Constant & 2.426 & 2.076 & 1.483 & 1.483 \\
Government Effectiveness & $(37.19)^{*}$ & $(28.99)^{*}$ & $(7.44)^{*}$ & $(7.64)^{*}$ \\
& -.6778 & -.6194 & -.5455 & -.5550 \\
Terrorism & $(-10.49)^{*}$ & $(-11.20)^{*}$ & $(-8.09)^{*}$ & $(-8.437)^{*}$ \\
& & .0217 & .1840 & .1593 \\
Crime & & $(9.08)^{*}$ & $(7.82)^{*}$ & $(6.47)^{*}$ \\
Population & & & .1955 & .1977 \\
RSQ & & & $(3.48)^{*}$ & $(3.61)^{*}$ \\
$\mathrm{~N}$ & & & & $9.62 \mathrm{e}-10$ \\
\end{tabular}

The Table is organized in a fairly typical way. The first column lists the potential explanatory variables. Each of the remaining columns show the results of a single regression run. When an explanatory variable enters an equation, then its estimated coefficient is provided in the appropriate row and column of the table. The number underneath the estimated coefficient in parenthesis is its individual $t$-statistic. An asterisk under the $t$-statistic indicates that the corresponding variable in that equation is significant at the one percent level of significance or better. The equations are numbered in the first row. Finally, the last two rows in the table provide, for each equation, the $\mathrm{r}$ squared value (RSQ), and the sample size $(\mathrm{N})$, the number of countries entering an equation.

The Table consists of four equations. The first is simple regression of state repression on government effectiveness alone, while the second, third, and fourth are multiple regressions. The second, adds terrorism to government effectiveness as an additional explanatory variable. The third equation has three independent variables. They are government effectiveness, terrorism, and organized crime. Finally, the fourth, is a regression of state repression on all four explanatory variables, government effectiveness, terrorism, organized crime, and population size.

The results lend strong support to the notion that more effective government lowers state repression. Whether effective government is used as the sole explanatory variable as in equation one, or when controlling for one or more other variables, as in equations two, three, and four, the estimated coefficient on government effectiveness is negative and highly significant (at the one percent level of significance or better). Looking at the r-squared value for the first equation show that government effectiveness on its own accounts for over thirty eight percent of the cross country variation in government repression in a sample consisting of one hundred and seventy eight countries.

The other three variables, terrorism, crime, and population also appear to be important determinants of terrorism. Whenever any of these variables appear in an equation, they are highly significant, and their estimated coefficients have theoretically correct signs. The coefficient for terrorism is positive and significant at the one percent level of significance in the three equations that it enters (equations (2), (3), \& (4)). Similarly, crime is positive and significant at the one percent level or better in the two equations it is used (equation (3) \& (4)). Finally, in equation four, the single equation in which population size appears, population size is positive and significant at the one percent level or better. The complete model, the four explanatory variables when used together, explain close to sixty nine percent of the cross country variation in state repression (equation (4)).

\section{Conclusion}


Effective government performance is what seems to really matter for keeping state repression at bay. The empirical analysis of this paper finds support for the hypothesis that more effective governments, because they have less need to do so, repress less. It also provides evidence that nations subject to greater terrorism, or nations more plagued by organized crime, engage in more repression. Whether it is in the area of providing public goods, ensuring a vibrant economy, protecting citizens from criminals and criminal activity, or from the ugly consequences of terrorism, it appears that governments posting higher marks in achieving desired public outcomes use less repression.

What all this means for repression policy is fairly clear. In order to achieve low levels of repression, citizens, to the extent that they have the power to do so, and autocratic rulers, to the degree they want to sustain public legitimacy for their government, must push for policies to achieve better government performance. Governments need to employ competent and able people, provide incentives for government officials, administrators, and workers to do their jobs well, and establish efficient governmental organizational and institutional structures.

Governments want to survive, and, if necessary, will use repression in order to do so. It is the failure of the government to perform that leads to repression.

\section{References}

Gibler, D. M. (2008). United States Economic Aid and Repression: The Opportunity Cost Argument. The Journal of Politics, 70(2), 513-526. http://dx.doi.org/10.1017/S002238160808047X

Institute for Economics and Peace. (2015). Vision of Humanity Website. Global Terrorism Index. Retrieved March 19, 2015, from http://www.visionofhumanity.org/\#/page/indexes/terrorism-index

Krieger, T., \& Meierrieks, D. (2009). What Causes terrorism? Retrieved May 7, 2015, from https://www.researchgate.net/profile/Daniel_Meierrieks/publication/5224314_What_causes_terrorism/links/0 2e7e52488fcfe6874000000.pdf

Mitchell, S. M., Ring, J. J., \& Spellman, M. K. (2013). Domestic Legal Traditions and States' Human Rights Practices. Journal of Peace Research, 50(2), 189-202. Retrieved July 17, 2015, from http://www.saramitchell.org/mrspublished.pdf

Nordas, R., \& Davenport, C. (2013). Fight the Youth: Youth Bulges and State Repression. American Journal of Political Science, 57(4), 926-940. http://dx.doi.org/10.1111/ajps.12025

Political Terror Scale. (2010). Retrieved July 1, 2015, from http://www.politicalterrorscale.org/

Ritter, E. H. (2014). Policy Disputes, Political Survival, and the Onset and Severity of State Repression. Journal of Conflict Resolution, 58(1), 143-168. http://dx.doi.org/10.1177/0022002712468724

Sorens, J., \& Ruger, W. (2012). Does foreign Investment Really Reduce Repression? International Studies Quarterly, $\quad 56(2), \quad 427-436 . \quad$ Retrieved July $2, \quad 2015, \quad$ from http://www.dartmouth.edu/ jsorens/invrep2-final.pdf

The Economist 2010. Economist Intelligence Unit, Democracy index 2010. Retrieved August 21, 2014, from http://graphics.eiu.com/PDF/Democracy_Index_2010_web.pdf

Wood, R. M. (2008). A Hand upon the Throat of the Nation: Economic Sanctions and State Repression, 1976-2001. International Studies $\quad$ Quarterly, $489-513$. http://dx.doi.org/10.1111/j.1468-2478.2008.00512.x

World Bank. (2014). World Development Indicators. Retrieved May 20, 2014, from http://databank.worldbank.org/data/views/variableSelection/selectvariables.aspx?source=world-developmentindicators

World Economic Forum. (2011). The Global Competitiveness Report 2010-2011. Retrieved June 20, 2014, from http://www3.weforum.org/docs/WEF_GlobalCompetitivenessReport_2010-11.pdf

Wright, T. M. (2014). Territorial Revision and State Repression. Journal of Peace Research, 5(3), 375-387. http://dx.doi.org/10.1177/0022343314520822

\section{Copyrights}

Copyright for this article is retained by the author(s), with first publication rights granted to the journal.

This is an open-access article distributed under the terms and conditions of the Creative Commons Attribution license (http://creativecommons.org/licenses/by/3.0/). 